\title{
Cumulative exects of labor market distortions in a developing country
}

\author{
Pehr-J ohan Norbäck ${ }^{\infty}$ \\ The Research Institute of Industrial Economicsy
}

October 5, 2000

\begin{abstract}
A bstract
This paper considers a small op en economy with an input-output industrial structure that creates vertical linkages and multiple equilibria. An imperfect labor market is introduced by assuming unionized labor. It is shown that a deregulation of the labor market may trigger a large, discontinuous expansion of industrial output, as reduced wage-costs start a circular, cumulative process in which expansions of the up-and downstream industries promote each other. Centralization of collective bargaining may, however, also be conducive to industrialization.
\end{abstract}

Keywords: Vertical Linkages, M ultiple Equilibria, Labor U nions

J EL classi...cation: F 12, 011 , J 50

\footnotetext{
${ }^{x}$ am grateful to Harry F lam at the Institute for International E conomic Studies (IIES) at Stockholm University, for useful discussions and suggestions. I would also like to thank Sten Nyberg at the Department of Economics at Stockholm University, J ohan Stennek and Per Skedinger at the Research Institute of Industrial E conomics and Christina Lönnbladh for improving the language. Financial support from Marianneand $\mathrm{M}$ arcus $\mathrm{W}$ allenb erg Foundation is gratefully acknow ledged.

y Pehr-J ohan Norbäck, the R esearch Institute of In dustrial E conomics B ox 5501 SE-114 85 Stockholm. E-mail: PJ N @iui.se, I nternet: http:// www.iui.se, Telep hone: +4686654522 and Telefax: +468661 7969 .
} 


\section{Introduction}

A number of papers emerging from the "new" trade theory focus on pecuniary externalities, arising in models with imperfect competition and scale economies. Rodrik (1995), R odriguez - Claire (1996) and K rugman and Venables (1995) are some well-known examples. The interest in such models can partly be explained by the fact that they give rise to multiple equilibria. $\mathrm{O} n$ the positive side, these models can explain why an economy may be trapped in a bad equilibrium, but they can also provide normative conclusions and prescribe how government policy should be used to push the economy into a superior equilibrium.

Clearly, these properties make such models interesting for analyzing problems in developing economies. ${ }^{1}$ The purpose of this paper is to investigate to what extent labor market distortions, in terms of labor unions, can act as impediments to development. It will be shown that even if only a limited share of the population is unionized - a reasonable assumption for a developing country - the costs of this labor market distortion may be disproportionately high, since the economy is kept at a low level of activity.

A n open two-sector model, which draws on Venables (1996), is used to make this point. A central feature is then that an input-output structure in the modern, industrial sector creates complementarities or pecuniary externalities between an upstream industry (which uses labor in order to produce intermediate in put goods) and a downstream industry (which uses domestic and imported intermediate in puts, together with labor and sector-speci..c capital, in order to produce...nal goods).

Workers in each ..nal good producing ..rm are assumed to be unionized and union wages are determined through wage-bargaining. I start by investigat $i-$ gating the possible exects of the institutional setting being changed in favor of employers, thereby reducing union wages.

\footnotetext{
${ }^{1}$ T hese models for malize some previous id eas in develop ment economics such as R osen steinR odan's (1943) Big P ush or Scitovsky's (1954) work on externalities. For a presentation, see M atsuyama (1993) or K rugman (1992).
} 
W hen there are multiple equilibria, the following picture emerges: If the lowlevel equilibrium is the initial equilibrium, decreasing union wages will increase the downstream production of ..nal goods and, subsequently, the downstream producers' demand for intermediate inputs. For suфc ciently large wage cuts, domestic upstream ..rms can enter, thereby lowering downstream production costs since a larger variety of inputs becomes available. This, in turn, facilitates additional downstream expansion. A cumulative, circular process is then begun, where expansion in the up- and downstream industries reinforce each other, thereby triggering a discontinuous jump from the low-level equilibrium to the high-level, industrialized equilibrium.

W hile a deregulation of the labor market may shift equilibrium, I also show that centralization of collective bar gaining can be conducive to indust rialization. In this case, a central union (which organizes all labor) and an employer's organization ( which serves the interests of all ..rms) negotiate an encom passing wage for the whole industry sector. The union side then internalizes that a reduction in the union wage is compensated by a signi..cant increase in union employment as the economy shifts from the low-level equilibrium to the high-level, industrialized equilibrium.

The model is mainly applicable to developing countries, although the mechanisms described can also be generalized to developed countries. The economy is small on the world market, which implies that the number of foreign intermediate inputs and their price, as well as the world market price of ..nal goods, are taken to be completely exogenous. Domestic intermediate inputs are not exported. ${ }^{2}$ Labor market institutions constitute a segmented labor market where workers in the upstream industry and the agricultural sector receive competitive wages, whereas a close relationship betwen the unions in the rent-yielding ..nal good industry and the political system, enables the unions to extract excess wages.

In relation to the literature, this paper contributes by introducing labor

\footnotetext{
${ }^{2}$ Exports of upstream goods can easily be included.
} 
unions in a context of vertical linkages and multiple equilibria. ${ }^{3}$ Using this new framework, the paper demonstrates how large wage-inequalities in favor of unions in key industries can have considerable exects on industrial output and employment in developing countries. It then points to the importance of maintaining competitive labor markets, or the use of centralized wage-setting, during transition. In dixerent models, A gell and Lommerud (1993) and Moene and Wallerstein (1997) also ..nd that centralized unions, which eliminate interindustry wage dixerentials, can improve economic eф ciency. In Agell and Lommerud (1993), however, wage inequalities are assumed to arise competitively, whereas this paper assumes wage inequalities to arise from union wages. Hence, competitive labor markets work as an impediment to industrial ization in their model, wher eas competitive wages promote indust rialization in the present model. Moreover, A gell and Lommerud contains no explicit analysis of wagebargaining.

M oene and W al lerstein (1997) compare bargaining at thelevel of the ..rm and the industry, but assume that unions only have preferences over wages. In this paper, union preferences over both wages and employment play an important role for the wage restraint exercised by the union in central bargaining. Indeed, with utility increasing in employment, the union internalizes not only that a reduced union wage can increase employment in a particular equilibrium, it also takes into account how a reduced union wage can discretely increase employment by shifting the equilibrium. This is precisely how centralized wage-setting enables to internalize the vertical linkages.

The paper is organized as follows. Section 2 describes the model and section 3 investigates the relationship between unions and industrialization. Section 4 concludes.

\footnotetext{
${ }^{3}$ There is a large literature on collective bargaing, where the exects of various types of externalities are discussed ( for a survey, see Flanagan (1999)). Even though input externalities have been noticed (see, for example Wallerstein (1990)), the above context, involving vertical linkages and multiple equilibria is, to my knowledge, new.
} 


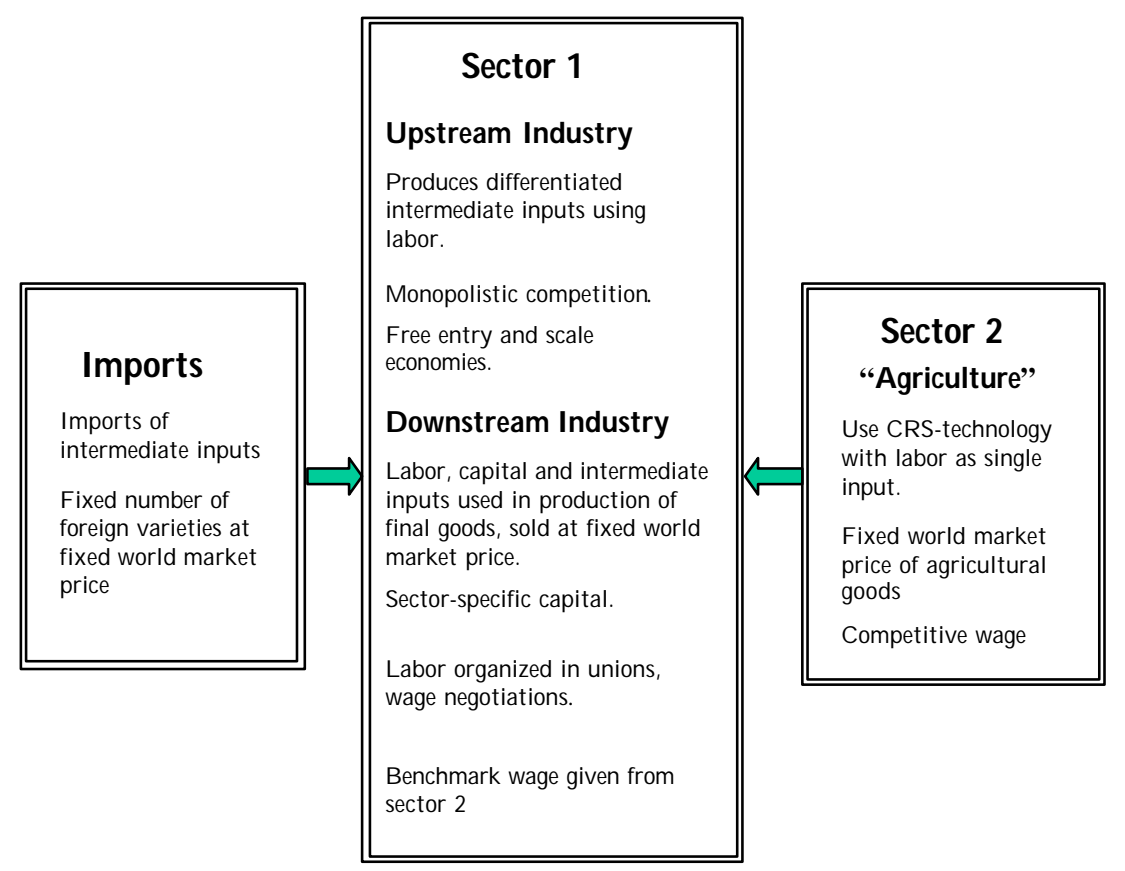

Figure 1: The structure of the model

\section{The model}

The basic structure of the model is shown in ..gure 1. The focus is on a small open economy with two sectors and labor as the common factor exogenously ..xed at L. The industrial sector, sector 1 , has two industries. The upstream industry, $X$, employs labor for producing dixerentiated intermediate input goods, which are combined with imported dixerentiated inputs, labor and sector-speci..c capital into a ..nal good in the downstream industry, $Y$. Final goods are tradable on the world market and can be sold at the ..xed world-market price q: Sector 2 constitutes the rest of the economy, and will be referred to as the agricultural sector. A gricultural goods, which will be used as numeraire, are produced with labor using a constant returns to scale technology and are also tradable at the world-market price. 


\subsection{Production}

The downstream industry is perfectly competitive. I follow the literature and depict this industry by using a representative ..rm. ${ }^{4}$ The production of ..nal goods requires three distinct inputs; labor, capital and intermediate inputs. Using the Cobb-D ouglas technology:

$$
Y=X{ }^{a} L_{Y}^{b} K{ }^{1_{i}} a_{i} b
$$

where $\mathrm{a}$ is the expenditure share of intermediate inputs, $\mathrm{X}$ is the amount used of a bundle of intermediate inputs (de..ned below), $L_{Y}$ is employment in the downstream industry and the production function $Y(\Phi$ exhibits constant returns to scale (CRS). In the production of ..nal goods, intermediate inputs are assembled into an aggregate input good $X$; de..ned in (2):

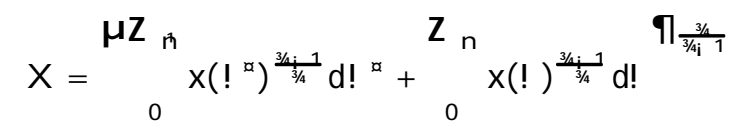

where $x$ is the amount used of a single variety, whereas ! $\left(!{ }^{\natural}\right)$ indicates domestic (foreign) varieties. $\mathrm{n}$ and $\mathrm{h}$ are the number of available domestic and foreign varieties, where the latter is taken to be..xed in accordance with our assumption of a small open economy and $3 / 42(1 ; 1)$ is the elasticity of substitution between two varieties. Using (2), we may de.ne the minimum-cost for one unit of the intermediate in put bundle $X ; P$, as:

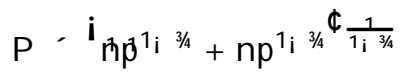

where $p$ is the price of domestic varieties, whereas $\beta$ is the ..xed world-market price of foreign varieties. Since varieties of intermediate inputs are imperfect substitutes, additional intermediate inputs enhance the ed ciency in downstream production, as illustrated by the price index which is decreasing in $\mathrm{n}$ :

The capital stock is sector-speci..c, so that capital can only be used in ..nal good production. We then normalize so that $k^{k}=1$ : The production function

\footnotetext{
${ }^{4}$ See, for example, O swald (1982).
} 
for ..nal goods (1) then becomes:

$$
Y=X^{a} L_{Y}^{b}
$$

The representative ..rm takes the price for the bundle of intermediate in puts $P$ as given. For a given wage in the downstream industry $w$ and a given worldmarket price for ..nal goods, q, pro..t-maximizing yields the pro..t function:

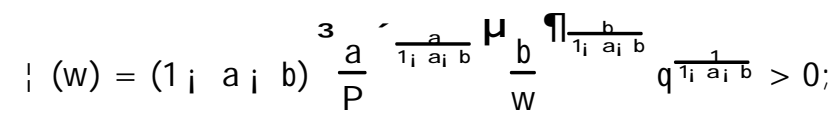

where $\quad(w)>0$ follows from $1 ; a_{i} b>0$. This pro..t may be interpreted as compensation to the owners of the ..rm's capital stock $K$ (the speci..c factor): Furthermore, the supply function is:

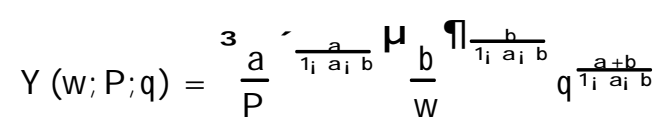

Next, we turn to upstream ..rms, where monopolistic competition is the upstream market form. From (3) and (5), it can be shown that the demand faced by an individual domestic intermediate input producer is:

$$
X=P^{3 / 4}{ }^{1} p^{13 / 4} \text { aqY }
$$

In this demand function, the individual upstream ..rm takes the price index $P$ and the downstream expenditure on dixerentiated goods, aqY, as given.

$T$ here is a unit labor requirement in production and a ..xed cost $F$ in terms of labor for entering the market. Assuming free entry and exit, and using the demand function (7), the pricing condition and zero-pro..t condition can be written as:

$$
\mathrm{p} 1 \mathrm{i} \frac{1}{3 / 4}^{\prime}=\mathrm{W} ; \quad \mathrm{px}=\mathrm{W}(\mathrm{x}+\mathrm{F}) ;
$$

where $w$ is the wage paid to upstream workers. These two equations determine a unique size of each domestic ..rm:

$$
X=\left(\begin{array}{ll}
3 / 4 ; & 1
\end{array}\right) F
$$


We can use (3), (7), (8) and (9) to derive the number of domestic intermediate input producers $n$, for a given level of ..nal good production $Y$ and a given upstream wage w:

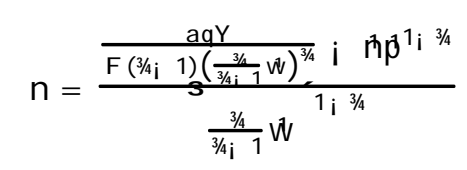

N ote that (10) implies a minimum level of ..nal good production to be associated with active domestic production of dixerentiated inputs. Setting $n=0$ in (10), we can derive:

$$
Y_{C}=A_{1} W^{3 / 4}{ }^{i} \beta^{1 i^{3 / 4}}
$$

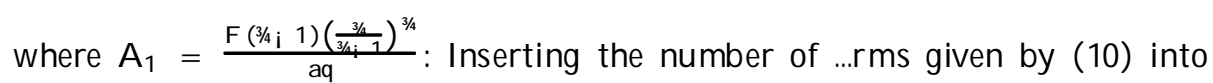
(3) and using the pricing rule (8), the unit cost of input bundles $X, P^{S}(Y)$; becomes:

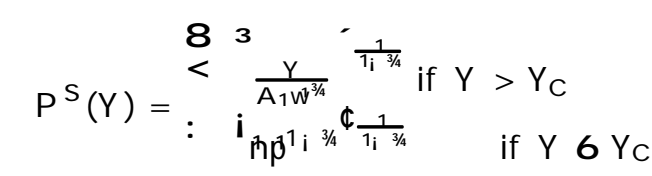

Equations (10), (11), (12) and (6) describe the vertical linkages in the model. Note that $\mathrm{P}^{\mathrm{S}}(\mathrm{Y})$ then consists of two segments. For $\mathrm{Y} 6 \mathrm{Y}_{\mathrm{C}}$, no domestic production of dixerentiated inputs occurs. The demand from ..nal good producers is insu $\varnothing$ cient for the existence of any domestic upstream ..rm, as entry costs cannot be recovered. Foreign imports only are used, so that ..nal good producers face a ..xed price for the aggregate input good $X$.

If ..nal good production increases so that $Y>Y_{C}$, domestic upstream ..rms will enter; this is the demand linkage (cf. equation (10)). A $n$ increasing number of suppliers of dixerentiated input goods enhance productivity in the downstream industry, since a larger range of dixerentiated in puts becomes available. $T$ his lowers downstream production costs as the unit cost of the input bundle $P(Y)$ decreases; this is the cost linkage (cf. equation (12)). A lower unit cost of the aggregate input good will then increase the supply of ..nal goods $Y$ (cf. equation (6)), and an increase in output may become cumulative, due to these vertical linkages. 


\subsection{Labor market}

The downstream industry is unionized and each ..nal good producing ..rm is assumed to have a separate union. The wage for downstream workers is determined in negotiations between the representative ..rm and the representative union. Using the $\mathrm{N}$ ash-bargaining solution, the negotiated wage $\mathrm{w}$ is de..ned as $\mathrm{w}_{\mathrm{f}}=\arg \max \mathrm{G}_{\mathrm{f}}$, where:

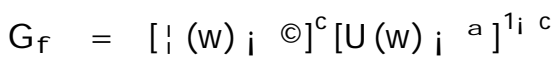

$$
\begin{aligned}
& U(w)=\left(L_{Y}\right)^{\circ}\left(w_{i} W\right)^{\mu} ; \quad c_{;}^{\circ} ; \mu 2(0 ; 1) ;
\end{aligned}
$$

where $c$ is the bargaining power of the ..rm, pro..ts ; (w) are given by (5) and the demand for labor $L_{Y}=i \frac{\varrho_{1}(w)}{@ w}$ follows from Hotelling's Lemma. ${ }^{5}$ The status quo pay-oxs of the ..rm and the union are de..ned as as arbitrary constants a , 0 and $\odot, 0.6$ The union has preferences over excess wage $\left(w_{i} w\right)$ and downstream employment $L_{Y}$ of the Stone-Geary type, where $\mu$ and ${ }^{\circ}$ are the excess wage and employment elasticities of the utility function. ${ }^{7}$ The comparison wage of an individual employed in the industrial sector is de..ned as $w^{\prime}=f_{L}^{0}$; where $f_{L}^{0}$ is the constant marginal product of labor in agricultural production. In other words, wis simply the competit ive wage paid in agricultural production and accordingly, the wage union members will receive if not employed in the downstream industry. Finally, note that the price of the intermediate input bundle $P$ is treated as ..xed in the pro..t function $;(w)$. At the level of an individual ..rm, the size and scope of the vertical linkages are too large to be internalized.

As shown in the appendix, the union wage then ful..lls:

$$
w_{f}=\left(w ; w_{m}\right) ; \quad \frac{d w_{f}}{d c}<0
$$

\footnotetext{
${ }^{5}$ See Varian (1992).

${ }^{6}$ It will be assumed that $U\left(w_{f}\right)+q\left(w_{f}\right)>(c+\underline{a}$ holds.

7 Pemb ert on (1988) derives $U$ ( $₫$ as the maximand of a "managerial union" with a leader ship interested in size (employment) and union members (median worker) interested in excess wages. Parameters $\mu$ and ${ }^{\circ}$ then corresp ond to the bargaining power of workers and leadership, respectively.
} 
where $w_{m}$ is derived from the limiting case of a monopoly union $(c=0)$. Since upstream workers are paid the competitive wage $w$, it is clear from (14) that downstream workers earn a wage premium compared to upstream and agricultural workers. All workers are then assumed to have the same skills, that is, the labor market is segmented. There is, however, no unemployment. The labor market condition $L=L_{X}+L_{Y}+L_{A}$, where the ..rst two terms represent the demand for labor in industrial production, determines the level of employment in agriculture $L_{A}$; which, in turn, determines the size of the agricultural sector.

\subsection{Solving the model}

A simple intersection of supply and demand price curves is used for solving the model. Following Markusen (1989), it will be solved by using the price of the aggregate intermediate input good $X$, rather than the price of an individual variety, $\mathbf{x}$ : Due to the presence of vertical linkages in this model, these prices will be expressed in ..nal good production $Y$ :

The supply function for ..nal goods, $Y(w ; P)$; is given in (6). This function may be inverted in order to derive the maximum price that ..nal good producers are prepared to pay for the aggregate intermediate input good $X$; for a given level of output $\mathrm{Y}, \mathrm{P}^{\mathrm{D}}(\mathrm{Y})$ :

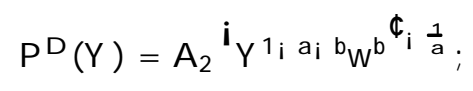

where the union wage $w$ is given from (14) and $A_{2}=a q^{\frac{a+b}{a}} b^{\frac{b}{a}}$.

A corresponding supply price must also be found in order to derive an equilibrium. That is, we need to ..nd the minimum price at which the upstream suppliers will supply the aggregate intermediate input good. However, this is only the unit cost for $\mathrm{X}, \mathrm{P}^{\mathrm{S}}(\mathrm{Y})$; which was derived in (12) by using the pricing rules of the individual ..rms (8).

The graphical solution is depicted in ..gure 2. First, note the segmented supply price curve $\mathrm{P}^{\mathrm{S}}(\mathrm{Y})$. A gain, $\mathrm{P}^{\mathrm{S}}(\mathrm{Y})$ is constant for $\mathrm{Y} 6 \mathrm{Y}_{\mathrm{C}}$, since ..nal good production is too small to admit domestic input production and only a 


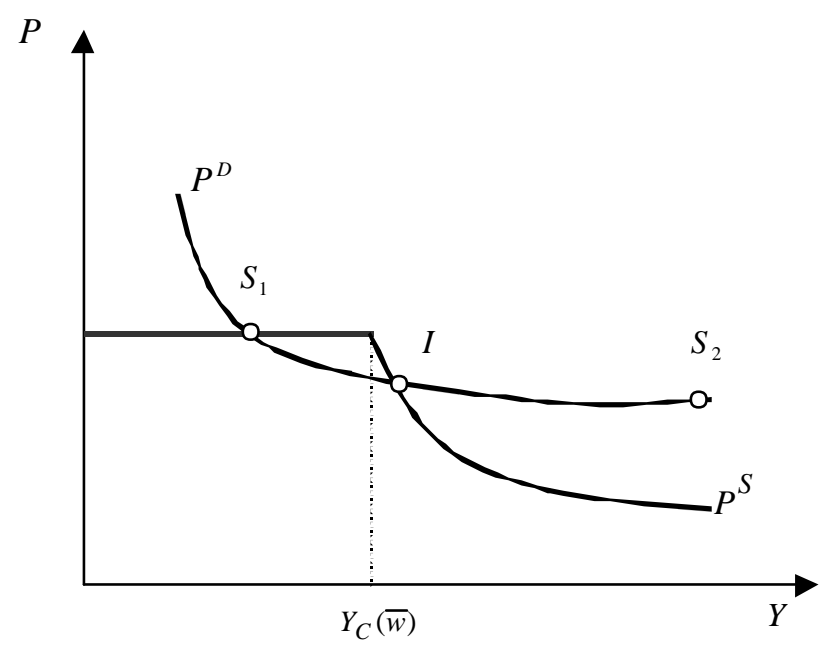

Figure 2: Multiple equilibria

..xed number of foreign varieties enter the price index at a ..xed price. However, as downstream output expands beyond $Y>Y_{C}$, entry of upstream ..rms occurs, thereby lowering the price index $P$ (c.f equation (3)). The demand price curve $\mathrm{P}^{\mathrm{D}}(\mathrm{Y})$ is downward-sloping for all levels of ..nal good production $Y$, due to the diminishing returns in ..nal good production arising from the ..xed factor. This reduces the price the downstream industry can pay for inputs at successively higher output levels.

As shown in the appendix, multiple equilibria arise if the cost- and demand linkages are suф ciently strong. In Figure 2 , there are three equilibria $\mathrm{S}_{1} ; \mathrm{I}$ and $\mathrm{S}_{2}$, the stability of which can be examined as follows: Due to pro..t maximization, ..nal-good producers increase production whenever the demand price for the aggregate input good exceeds the supply price, $P^{D}(Y)>P^{S}(Y)$, whereas they reduce production whenever $\mathrm{P}^{\mathrm{D}}(\mathrm{Y})<\mathrm{P}^{\mathrm{S}}(\mathrm{Y})$. In addition, assuming that upstream producers enter in response to instantaneous pro..ts, upstream ..rms will enter whenever $P^{D}(Y)>P^{S}(Y)$, given that downstream supply is initially suc ciently large, $Y, Y_{C}$. To see this, note that the former condition states an excess demand on the aggregate intermediate input good $X$, thereby imply- 
ing that there must also be an excess demand for individual varieties $\mathrm{x}$. Since $\mathrm{P}^{\mathrm{S}}(\mathrm{Y})$ is derived by imposing zero pro..ts on upstream ..rms, individual ..rms must make positive pro..ts and entry takes place. For the same reason, upstream ..rms exit when $\mathrm{PD}(\mathrm{Y})<\mathrm{PS}^{\mathrm{S}}(\mathrm{Y})$ and $\mathrm{Y}, \mathrm{Y}_{\mathrm{C}}$.

Making use of this information, I must be unstable, whereas $S_{1}$ and $S_{2}$ are stable. Note that $S_{1}$ occurs for $Y 6 Y_{C}$, so that ..nal good production cannot sustain any domestic upstream production and only imported intermediate inputs are used. $O$ ne the other hand, $S_{2}$ is an equilibrium where the economy is completely specialized in industrial production and all labor resources are devoted to industrial production.

\section{Unions and development}

In this section, I will study how labor market policy be can used to axect the economy. I will discuss two quite opposite policies: First, I will examine a deregulation of the labor market, then, the exects of centralization of wagenegotiations.

\subsection{Deregulating the labor market}

To put the analysis in a developing country-context, suppose the economy is in the low-level equilibrium $S_{1}$. Then, assume that an institutional change occurs, where the government intervenes on the labor market by weakening the unions' ability to mark-up wages in ...nal good production. ${ }^{8}$ In this model,

\footnotetext{
${ }^{8}$ Uni on bargaining power will dep end on the unions' right to organize the supply of labor and their ability to inłict damage on ..rms during a conłict. Theright to organizeand theright to strike is governed by the institutional framework in the economy, however. Institutional changes may then axect their bargaining power in several ways. Such changes may decrease the incentive to become a member of a union. With a smaller number of members, the union is weaker in its negotiations with the ..rm, which will be the result if union control over labor supply is diminished by limiting the legal bargaining monopoly of the unions. Reformation of employment security laws is another example. In this case, the ..ring costs for the ..rms will decrease.
} 


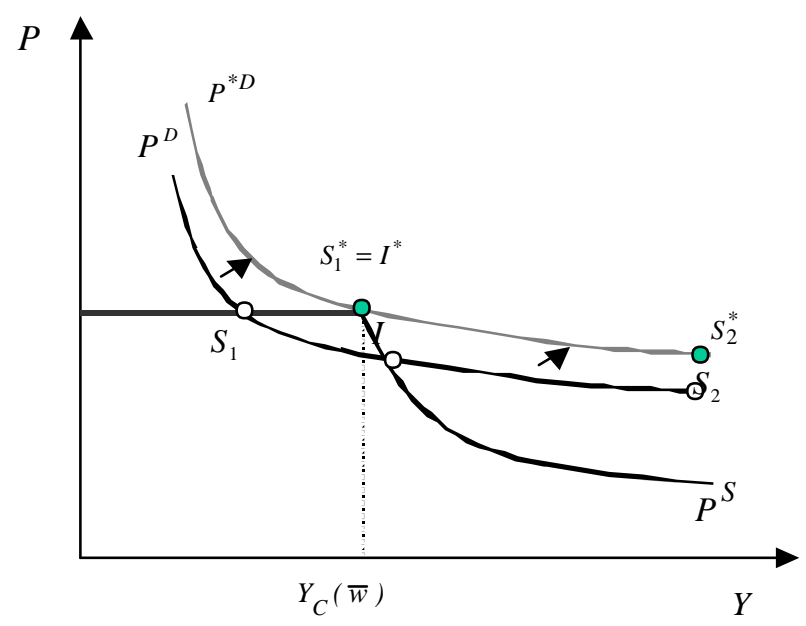

Figure 3: Der egulating the labor market

I simply assume that this will increase the bargaining power of the ..rms in the downstream industry, c. By (14), this implies a decreased wage mark-up and thus a decreased union wage $w_{f}$, which will shift the demand price curve $\mathrm{P}^{\mathrm{D}}(\mathrm{Y})$ upwards, due to decreasing downstream wage costs, but will not axect the supply price curve $\mathrm{P}^{\mathrm{S}}(\mathrm{Y})$, as upstream workers are still paid the competitive wage. Thus, downstream output expands as $S_{1}$ is shifted to the right, as is illustrated in ..gure 3. It can also be noted that the unstable equilibrium I moves backwards. Indeed, if the increase in c is su $₫$ ciently large, the wage cuts in the downstream industry may cause $S_{1}$ and $I$ to coincide, as $P^{D}(Y)$ shifts upwards to $\mathrm{P}^{\mathrm{x}} \mathrm{D}(\mathrm{Y})$.

$B y$ inducing further wage cuts, the deregulation may shift the demand price curve out side the supply price curve. When $P D(Y)$ shifts further to the right in ..gure 3 , so that $P^{D}(Y)>P^{S}(Y)$, this generates entry of domestic upstream ..rms which, in turn, further reduces the production costs of the downstream ..rms through a greater range of available inputs, thus facilitating additional downstream expansion. A circular, cumulative process is begun where the expansion in the up- and downstream industries reinforce each other. Cumulative 
causation will take the economy out of the low-level equilibrium $S_{1}$ and into the new industrial equilibrium $S_{2}^{\sharp}$, where the economy is completely specialized in industrial production. ${ }^{9}$

In summary:

P roposition $1 \mathrm{~A}$ deregulation of the labor market can have potentially very large exects. It can generate a shift from the low-level equilibrium to the highlevel equilibrium.

\subsection{Centralized wage-setting}

Proposition 1 indicates that the government should restrict union power. However, as argued in the liter ature on macro-economic performance and collective bargaining (for a survey, see F lanagan (1999)), wage external ities are mor e exectively internalized when wage-setting becomes more centralized. This section therefore investigates if industrialization can be achieved by a reform of the wage-setting process. To keep the exposition simple, I will present the case of centralized wage-setting in the industrial sector, where a common wage is negotiat ed for upstream- and downstream labor.

Suppose that the government can inłuence the labor market, so that a central union and a central employer organization are created in the industry sec$\operatorname{tor}^{10}$. The union, which organizes all labor, and the employer federation, which

\footnotetext{
${ }^{9} \mathrm{~T}$ his result is quite extreme, but ari ses as the competitive wage is unaxected by industrial expansion. It is, however, easy to "convexify" the model by introducing a ..xed factor, that is, land, in agriculture. Then, as industrial expansion draws labor from the agricultural sector, an increasing land/ labor ratio increases the competitive wage. A dding this general equilibrium exect to the cost-linkage will tend to make the supply price curve $U$-shaped, which, in turn, makes it possible to derive the high-level equilibrium $\mathrm{S}_{2}$ through intersecting demand and supply price curves, so that $S_{2}$ becomes an equilibrium without specialization. This improved real ism, however, comes at the cost of analytical tractability. But it is easily shown that the qualitative exects of a deregulation do not change in the extended model

${ }^{10}$ I shall just assume that the government can provide a forum through which negotiations can be initiated. Having established contacts, the parties may ..nd that there are gains from cooperation to be exploited, as is shown in the example of centralized wage-setting and "solidaristic wage policy" in the ind ustrial sector.
} 
serves the interests of all ..rms, then negotiate an encompassing wage for the whole industrial sector. The wage in the agricultural sector continuous to be set competitively.

In contrast to decentralized bargaining, the central union and the employer federation can take into account the vertical linkages between downstream and upstream ..rms. It is then useful to derive the maximum encompassing union wage, $w$; which is compatible with industrialization and a shift from the lowlevel equilibrium to the high-level equilibrium. $N$ ote that since upstream workers receive union wages, the critical level of ..nal output $Y_{C}$ can be found by simply substituting the competitive wage $w$ for the critical union wage in (11), to get:

$$
Y_{C}(w)=A_{1} w^{3 / 4} i h p^{1 i \frac{3}{4} 4^{i}}
$$

Setting downstream supply (6) equal to the critical output (16) and using (12), we have:

$$
W=\left(A_{3}\right)^{\left.\frac{1}{3 /(1 ; i a j i} a_{i} b\right)+b}
$$

where $A_{3}$ consists of the various parameters in the model. ${ }^{11}$

This exercise is illustrated in ..gure 4. At an industry wage $w>w$, there are three equilibria $S_{1} ; I$ and $S_{2}$ : In $S_{1}$, the union wage, $w_{1}$, say, leads to a supply of ..nal output insu $\varnothing$ cient to sustain domestic upstream ..rms as downstream production is below the critical level, $Y_{C}\left(w_{1}\right)$. To push the economy to $S_{2}$; the industry wage must be reduced which, in turn, shifts the demand price curve $\mathrm{P}^{\mathrm{D}}(\mathrm{Y})$ upwards and the supply-price curve $\mathrm{P}^{\mathrm{S}}(\mathrm{Y})$ downwards. The latter shift occurs since lower wage costs for the upstream ..rms reduce the price of

\footnotetext{
${ }^{11}$ It is tedious, but straightforward, to show that:

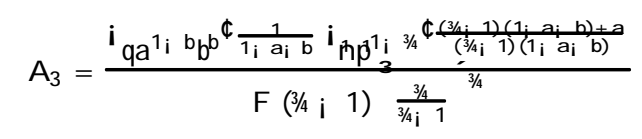




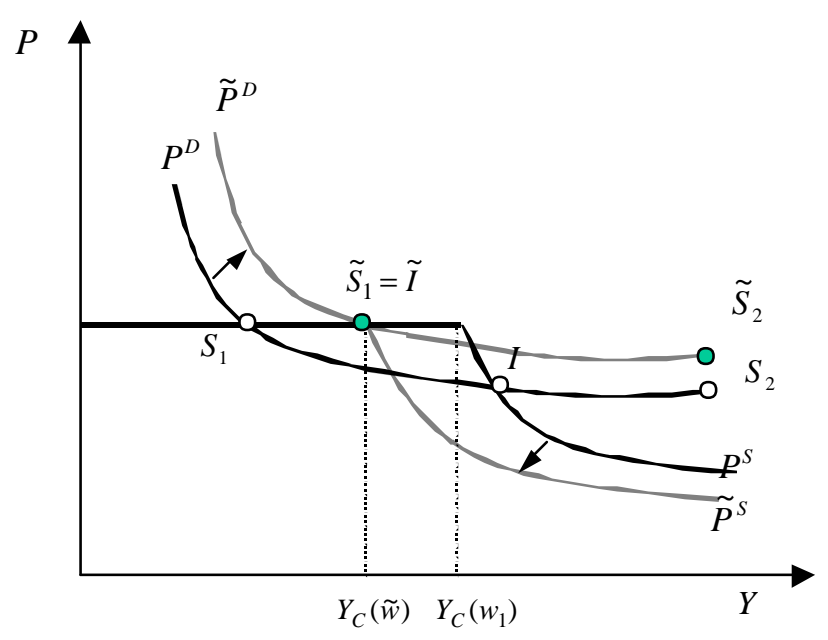

Figure 4: Centralized wage-setting

individual varieties of inputs. ${ }^{12}$ At $w=w$; the two curves coincide, $P D(Y)=$ $\mathrm{p}^{\mathrm{S}}(\mathrm{Y})$. It is then clear that if the union wage is set marginally below $\mathrm{W}$, downstream ..rms will expand their production beyond $Y_{C}\left(w_{*}\right)$. As the demand price exceeds the supply price, $\mathrm{P}^{\mathrm{D}}(\mathrm{Y})>\mathrm{P}^{\mathrm{S}}(\mathrm{Y})$, upstream ..rms enter and the cumulative forces working through the cost- and demand linkages will push the economy to the high-level equilibrium $\boldsymbol{S}_{2}$.

In summary:

Lemma 2 To facilitate industrialization and shift the economy from the low level equilibrium to the high-level equilibrium, the encompassing union wage must ful..ll (18):

$$
w<w
$$

\footnotetext{
${ }^{12}$ To see this, substitute the competitive wage $w$ for the critical union wage $w$ in equation (8). That a reduction in the encompassing wage indeed reduces the supply price, can be seen by substituting the competitive wage $w$ for the critical union wage $w$ in equation (12).
} 


\subsubsection{W hy may centralization be conducive to development?}

Formally, the industrial wage negotiated by the central union and the employer federation can be derived by using the Nash-bargaining solution, de..ned as $\mathrm{W}_{\mathrm{e}}=\arg \max \mathrm{G}_{\mathrm{e}}$, where:

$$
\begin{aligned}
G_{e} & =[U(w) i \S]^{1 i c}[S(w) i \quad]^{c} \\
S & =1+n^{1 / x} ; \quad U=\left(L_{\mid n d}\right)^{o}(w i \quad W)^{\mu} ; \quad L_{x}=n(x+F)
\end{aligned}
$$

The employer-federation's pay-ox is the aggregated pro..t made by upstream and downstream ..rms at the union wage $w, S(w)$. The central union's pay-ox is $U(w)$, where we can note that union employment now becomes industrial employment, $L_{I_{n d}}=L_{Y}+L_{X}$, as labor in both upstream and downstream ..rms receive the union wage $w$. The status quo pay-oxs of the central union and the employer federation are de..ned as arbitrary constants $\S$ and $\odot .{ }^{13}$

Due to non-linearities, it is very diф cult to explicitly solve (19). However, as proved in the appendix, the following proposition holds:

P roposition 3 If the labor force is suc ciently large and the central union is suф ciently employment-oriented, centralized wage-setting induces industrialization and shifts the economy from the low-level equilibrium to the high-level equilibrium.

The intuition is straightforward. The proposition simply describes conditions which need to be ful..lled for both parties to prefer a low union wage leading to ind ustrialization $(w<w)$ to a higher wage which does not $(w, w)$.

E mployers always prefer a low wage associated with industrialization: $F$ irst, pro..ts increase when wage costs are reduced. In addition, downstream ..rms gain from having a larger range of inputs available as the entry of domestic upstream ..rms also improves productivity: T he latter is easily seen from ...gure 4 , where the supply price $\mathrm{P}^{S}$ in $\mathrm{S}_{1}$ exceeds the corresponding supply price in $\mathrm{S}_{2}$.

\footnotetext{
${ }^{13}$ We shall assume that $\mathrm{U}\left(\mathrm{w}_{\mathrm{e}}\right)+\mathrm{S}\left(\mathrm{w}_{\mathrm{e}}\right)>\S+\odot$ holds.
} 
The intuition to why the union-side might prefer to restrict its wage demands stems from the fact that choosing a wage below $w$ is compensated by a massive, discrete expansion of union employment. To see this, note that at a high wage $w>w$, union members originate solely from downstream ..rms, as the economy is kept in the low-level equilibrium $S_{1}$. By agreeing to a low wage, $w<w$; domestic upstream ..rms enter and the cumulative forces push the economy towards the high-level equilibrium $\boldsymbol{S}_{2}$. However, in $\boldsymbol{S}_{2}$ the economy specializes in industrial production and both upstream and downstream workers are organized in the encompassing union ${ }^{14}$. Given that the union values employment suф ciently (i.e. when $\frac{H}{\circ}$ is suф ciently low) and the economy is suc ciently large (in terms of $L$ ), the central union will prefer a low wage leading to industrialization to a high wage which does not.

As shown in the appendix, this is the case whenever:

$$
\frac{L}{L_{Y}\left(w_{1}\right)}>{\frac{w_{1} i w^{9 !}}{w_{2} i w^{\prime}}}^{9}
$$

where I have generally de. ned two alter native wages $w_{1}>w$ and $w_{2}<w$.

\section{Conclusion}

In this paper, I have shown that labor market imperfections may have considerable exects in an environment with scale economies and imperfect competition, where pecuniary externalities and vertical linkages exist between ..rms.

It was shown that a "deregulation" of the labor market may trigger a discontinuous expansion of output, as the economy moves between equilibria. This process worked through the "positive feedbacks" inherent in this type of economy. As ..nal good producers increased production in response to reduced wage

\footnotetext{
${ }^{14} \mathrm{~A}$ gai $\mathrm{n}$, special ization is an extreme result which originates from simplifying assumptions. The mechanism is, however, more general. Even if the the high-level equilbrium would not entail special ization, the union would still trade ox that a reduced wage increases empl oyment far beyond the usual continuous expansion, as the economy shifts from the low- to the high level industrialized equilibrium.
} 
costs, upstream producers bene.tted through higher demand for inputs. This permitted entry of additional upstream ..rms, which reduced production costs for ...nal good producers even further, through a more eф cient use of intermediate inputs.

As noted by several writers, the existence of such "positive feedbacks" indicates a coordination failure betwen ..rms, since the pecuniary externalities are not internalized by, for example, vertical mergers. ${ }^{15}$ Union wage policy may worsen this coordination failure, which is the very reason for the potentially considerable exects of policies aiming at deregulating the labor market. ${ }^{16}$

However, the large potential costs arising from high union wages in key industries also imply that there are large potential gains from centralization of wage bargaining. Indeed, the model shows that when the union is an encompassing union eliminating the wage dixerential between upstream and downstream labor, the union internalizes the wage externality and lowers its wage demands in return for a very large increase in industrial employment and, hence, a large increase in union membership.

G overnment policies may then aim at weakening the unions or try to accomplish a centralization of collective bargaining to prevent wage inequalities which might im pede development. ${ }^{17}$ Centralization of collective bargaining might be dic cult to implement in practice, since it requires that coalitions of heterogenous agents have to be formed on both the employer- and the union side. ${ }^{18} \mathrm{~A}$

\footnotetext{
${ }^{15}$ Such internalization may fail to materialize, partly becau se the scope of the linkages may be considerable, but also because the incentives for an individual ..rm to take these "positive feedbacks" into account, are much smaller than the social bene.t.

${ }^{16} \mathrm{High}$ uni on wages is only one fact or among several which may preserve the economy in a low-level equilibrium. As is shown in Venables (1996), import substitution policies through tarixs on imported inputs may also reduce industrial output by increasing downstream costs. ${ }^{17}$ It is then interesting to note that among the East-A sian NIC countries, wages have remained at market clearing levels and wage inequalities due to segmentation have been absent during their transition (World Bank (1993)). In Singapore, the government has used a "wagecorrection" policy (Fields (1992)).

${ }^{18}$ As argued by Lindbeck (1997), conłicts may arise within organizations rather than between peak organizations which may lead to a situation where centralized bargaining is not sustainable.
} 
deeper understanding of the relationship between dixer ent wage-setting institutions and economic development, however, requires a more elaborate framework which also models government behavior and the interaction within coalitions more explicitly. I believe that the type of model used in this paper could be fruitfully applied for such a task. 


\section{R eferences}

A gell, J . and K. E. Lommerud, 1993, E galit arianism and Growth, Scandinavian Journal of Economics, 95(4):559-579.

Binmore, $\mathrm{K}$. and A. Wolinski, 1986, The Nash bargaining solution in economic model ling, R and J ournal of E conomics, 17.

Calmfors, L, 1993, Centralization of wage bargaining and macroeconomic performance, OECD E conomic Studies 21.

Dixit, A.K. and J.E. Stiglitz, 1977, Monopolistic competition and optimum product diversity, A merican Economic R eview, 67:287-308.

Driф I, J . and F. Van der Ploeg, 1997, Trade liberalization with imperfect competition in goods and labor markets, Scandinavian J ournal of E conomics, 97:223-243.

Ethier, W .J. 1982, National and international returns to scale in the modern theory of international trade, A merican E conomic R eview, 72:389-405.

F ields, G.S., 1992, Changing Labor M arket C onditions and E conomic Development in Hong K ong, Korea, Singapore and Taiwan, China", B ackground paper for The East A sian Miracle World Bank, Policy Research Department, Washington DC.

F lanagan, R.J ., 1999, M acroeconomic Performance and Collective Bargaining: A n international Perspective, J ournal of Economic Literature, XXXVII, September:1150-1175.

Haggard, S., 1994, Politics and Institutions in the World Bank's East A sia, volume 11 of Policy Essay, Overseas Development Council, Washington, DC.

Harrison, A. and E. Leamer, 1997, L abor markets in developing countries: A n agenda for research, J ournal of $L$ abor E conomics, 15:1-19. 
Horton, S., R. K anbur, and D. M azumbar, 1991, Labor markets in an era of adjustment - Evidence from 12 developing countries, International Labor Review, 130.

K rugman, P.R., 1992, Towards a counter-counter revolution of development theory, In Proceedings of the World Bank Annual Conference on Development Economics.

Krugman, P.R. and A. Venables, 1995, Globalization and the inequality of nations, Quarterly J ournal of Economics, 60:857-880.

Lindbeck, A., 1997, T he Swedish Experiment, SNS F örlag.

M arkusen, J.R ., 1989, Trade in producer services and in other specialized intermediate inputs, A merican Economic R eview, 79:89-95.

M arkusen, J .R . and A .J . Venables, 1999, Foreign direct invest ment as a catalyst for industrial development, European E conomic Review v43, n2:335-56.

Matsuyama, K., 1993, Modelling complementarity in monopolistic competition, Monetary and Economic Studies v11, n1:87-109.

M oene, K.O. and M. Wallerstein., 1997, Pay Inequality, J ournal of Labor E conomics, 15, n3: 403-430.

M oene, K.O., M. Wallerstein and M. Hoel, Bargaining Structure and E conomic Performance, 1993, In F lanagan, M oene and W al lerstein, eds, Trade U nion Behavior, $\mathrm{P}$ ay Bargaining and $\mathrm{E}$ conomic Performance, Oxford: Clarend on Press.

Oswald, A.,1982, Trade unions, wages and unemployment; what can simple models tell us?, Oxford Economic Papers, 34.

P ack, H. and L. Westpahl, 1986, Industrial strategy and technological change: Theory versus reality, J ournal of Development Economics, 22:87-128. 
Pemberton, J., 1988, A managerial model of a trade union, The Economic J ournal, 98:755-771.

Pencavel, J ., 1997, The role of labor unions in fostering economic development, World B ank P olicy R esearch W orking Paper 1469.

Rodriguez-Clare, A., 1996, The division of labor and economic development, Journal of Development Economics, 49.

Rodrik, D.,1995, Coordination failures and government policy: A model with applications to East-A sia and Eastern Europe, J ournal of International Economics, 40 n1-2:1-22.

R osenstein-R odan,1943, Problems of industrialization of Eastern Europe and South-E astern E urope". E conomic J ournal, 53:202-211.

Scitovsky, T ., 1954, T wo concepts of external economies. J ournal of Political E conomy, 62:143-151.

Skedinger, P., 1992, E ssays on Wage Formation, Employment and U nemployment, PhD thesis, Uppsala University.

Varian, H., 1992, Microeconomic A nalysis, W.W. Norton \& Company, New York, London.

Venables, A .,1996, Trade policy, cumulative causation and industrial development, J ournal of Development E conomics, 49:179-197.

Wallerstein, M., 1990, Centralized bargaining and wage restraint, A merican J ournal of Political Science, 34.

World Bank, 1993, The East A sian Miracle: Economic Growth and Economic Policy, Oxford University Press. 


\section{A A ppendix:}

First, I brieły derive the union wage in the ..rm-level bargaining. Then, I show under what conditions multiple equilibria arise. Finally, I derive conditions for which centralized bargaining leads to industrialization.

\section{A.1 The union wage in ..rm-level bargaining}

$P$ roof. The ..rst-order condition for (13) is:

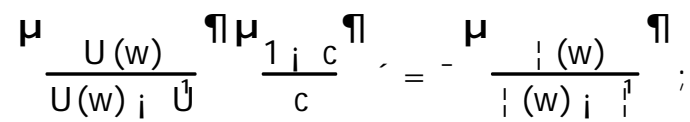

where " $=\mathrm{i} \frac{d \mathrm{~d}}{\mathrm{dw}} \frac{w}{L},{ }^{-}=\mathrm{i} \frac{d}{d w} \frac{w}{i}$ and where:

$$
=\frac{d U}{d w} \frac{w}{U}=\frac{\mu w}{w i w} i^{\circ}
$$

Note that $c 2(0 ; 1)$, implies that $U(w) ; U^{1}>0$ and $;(w) ;\left.\right|_{1} ^{1}>0$. This ensures that $w>W$ and ' $>0$. Furthermore, totally dixerentiating (A.1), it can be shown that:

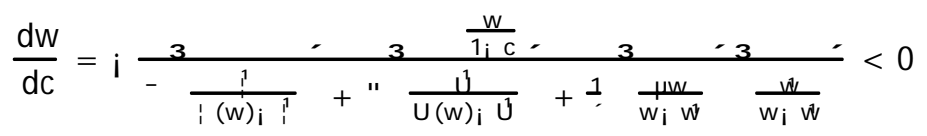

\section{A.2 Multiple equilibria}

P roof. First, de. ne the inequality (A .4):

$$
a^{3} / 4+(1 ; 3 / 4(1 ; b)>0
$$

Suppose there exists an equilibrium $S_{1}$ for which $Y<Y_{C}$. T hen, if (A .4) holds, equilibria I and $S_{2}$ must also exist. To see this, de.ne the elasticity $E L_{Y} P^{D}=$ $\mathrm{i} \frac{@ \mathrm{P}}{@} \frac{\mathrm{Y}}{\mathrm{PD}^{\mathrm{D}}}$ and similarly $E L_{Y} \mathrm{P}^{\mathrm{S}}$. B y calculation:

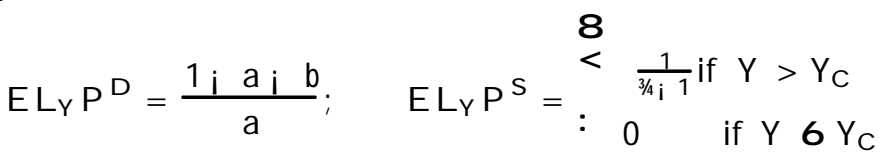


Then, note that for any $Y$ such that $P^{D}(Y)=P^{S}(Y)$, it must be that:

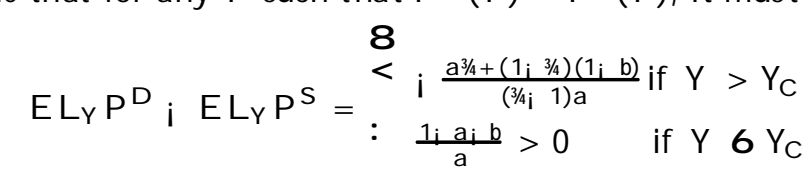

From the existence of $S_{1}$ and the segmented shape of the supply price curve (12), it then follows that a second equilibrium I exists if (A.4) holds. This is easily seen in ..gure 2, since (A.4) implies that $E L_{Y} P^{D} ; E L_{Y} P^{S}<0$, which, in turn, ensures that the demand price curve intersects the supply price curve from above at I. Due to pro..t-maximizing behavior, there must also exist a third equilibrium $S_{2}$ at which $P^{D}>P^{S}$ :

Moreover, it should be noted that (A.4) is directly related to the strength of the demand- and cost linkages (cf. equations (10), (11), (12) and (6)). Intuitively, the demand linkage is stronger when intermediate inputs are relatively important in ..nal-good production. This comes at a large cost-share of intermediate inputs $a$ and a smaller cost-share of capital $b$ which translates into a more elastic, or fatter, demand price curve $\mathrm{P}^{\mathrm{D}}(\mathrm{Y})^{19}$. Furthermore, at a smaller substitution elasticity $3 / 4$ downstream ..rms value variety in intermediate inputs more highly, as eф ciency is enhanced in a more pronounced way by additional inputs. As upstream entry occurs in response to an increase in demand from downstream ..rms, the price index $\mathrm{P}$ will decrease at a greater rate, thus producing a stronger cost-linkage. This translates into a less elastic, or steeper, supply price curve $\mathrm{P}^{\mathrm{S}}(\mathrm{Y})^{20}$. Indeed, both these prerequisites - an elastic demand price curve and an inelastic supply price curve - are more likely to ocurr when condition (A.4) holds.

\section{A.3 Proposition 3}

P roof. To show that proposition 3 is true, we need only show that the central union and the employer federation prefer a union wage below the critical wage w, de.ned by (18).

\footnotetext{
${ }^{19} \mathrm{~A}$ given decrease in the price index $\mathrm{P}$ results in a larger expansion of ..nal output.

${ }^{20} \mathrm{~A}$ given increase in ... nal out put $\mathrm{Y}$ results in a larger decrease in the price index $P$.
} 
W ithout loss of generality, suppose the parties are contemplating two alternative wages: $w_{1}, w$ associated with low-level equilibrium $S_{1}$ and $w_{2}<$ $w$ associated with $S_{2}$ in ..gure 4: To assure positive union utility, both wages exceed the competitive wage $\mathbf{w}$ : To summarize:

$$
w_{1}>w_{2} ; \quad w_{1}, w>w ; \quad w_{2} 2(w ; w)
$$

The employer side will always prefer $w_{2}$ : Downstream ..rms bene..t from lower input prices, since (i) wage costs are lower $w_{2}<w_{1}$ and (ii) the price of the aggregate input good $\mathrm{X}$ is lower, $\mathrm{P}_{\mathrm{S}_{2}}^{\mathrm{S}}(\mathrm{Y})<\mathrm{P}_{\mathrm{S}_{1}}^{\mathrm{S}}(\mathrm{Y})$. The latter follows directly from substituting the competitive wage $w$ for the union wage $w$ in equation (12) and noting that $w=w_{1}$ leads to equilibrium $S_{1}$ and $n=0$, whereas $w=w_{2}$ leads to equilibrium $S_{2}$ and $n>0$ : Furthermore, since $P D>P S$ holds in $S_{2}$, we know from section 2.3 that upstream ..rms make nonzero pro..ts; $1 / 4(w)>0$ :

Turning to the union side, note that the source of union employment in $S_{1}$ is $L_{\text {Ind }}\left(W_{1}\right)=L_{Y}\left(W_{1}\right)$. On the other hand, in $S_{2}$, union employment is $L_{1 \text { nd }}\left(w_{2}\right)=L$. The central union then prefers $w_{2}$ whenever $U\left(w_{2}\right)>U\left(w_{1}\right)$ : Using the above information and the union's preferences de..ned in (19), this condition can be written as:

$$
(L)^{\circ}\left(w_{2} ; W\right)^{\mu}>\left(L_{Y}\left(w_{1}\right)\right)^{\circ}\left(w_{1} ; W\right)^{\mu}
$$

Rearranging, we have that:

$$
\frac{L}{L_{Y}\left(w_{1}\right)}>{\frac{\mu}{w_{1} i w}}^{w_{2} i w^{\frac{1}{\sigma}}}
$$

Hence, if the union values employment suф ciently (i.e. when $\frac{H}{2}$ is suф ciently low) and the economy is suc ciently large (in terms of $L$ ), the central union prefers the lower wage, $w_{2}<w_{1}$ : 